\title{
Yield of soybeans depending on primary soil tillage and organic fertilizer aftereffect
}

\author{
V. G. Kutilkin, S. N. Zudilin*, and N. V. Chukhnina \\ Samara State Agrarian University, Kinel, 446442 Samara region, Russia
}

\begin{abstract}
Studies were conducted on an experimental field of Samara State Agrarian University in 20072019 with the purpose of studying the influence of primary soil tillage of typical heavy loam chernozem and aftereffect of different organic fertilizers on the yield of soybeans. The most optimal conditions for the soil density were determined by plowing, which was $0.90-1.10 \mathrm{~g} / \mathrm{cm}^{3}$ for the growth and development of soybeans. Primary tillage did not have any significant effect on the productive moisture reserves in the meter layer of soil. Shallow tillage and no-till contributed to a 1.3-time increase in weediness of soybean crops compared to plowing. The greatest crop yield $1.45 \mathrm{t} /$ ha was collected by plowing, which was 0.25 and 0.44 $\mathrm{t} /$ ha higher than by shallow tillage and no-till respectively. The aftereffect of organic fertilizers promoted the additional soybean yield of $0.17-0.18 \mathrm{t} /$ ha compared to the non-fertilized plot. New types of organic fertilizers were as good as manure in terms of impact on productivity.
\end{abstract}

\section{Introduction}

Increase of vegetable protein production is the most important task of modern agricultural production. Soy as a valuable food, feed and industrial crop has a special place among legumes in solving this problem. There are about 100 million hectares under soybean crops in the world that is explained by its high food, agronomic and environmental benefits Soybean is the most widespread high-protein oilseed crop in the world, widely used for technical, feed and food purposes.

It is especially widely cultivated in the United States, Brazil, Argentina, Canada, China, India, and Italy, and these countries currently account for up to $90 \%$ of global soy grain production. In the United States, 18 million tons of soybeans are used annually for animal husbandry alone, and the total gross harvest in recent years has reached 80 million tons.

Soy is a valuable crop that has no equal in protein content and quality. Its seeds contain $28-52 \%$ of fullfledged balanced amino acid protein and $16-27 \%$ of fat. Soy is widely used for the manufacture of many highly nutritious foods and various types of feed. Adding it to the feeding rations allows you to increase the productivity of livestock and poultry and use other feed more efficiently.

Expanding the area of soybean cultivation in arid regions, including the middle Volga steppes, makes it necessary to improve the methods of cultivation of this crop, among which an important place is occupied by soil cultivation and the introduction of herbicides to combat weeds. In the steppe zone, where the fields are flat and large fields, small and less stable snow cover, flat-cut and combined processing to a variable depth improve the water regime of the soil, compared to plowing and constant shallow processing.

The experience accumulated so far in the Samara Research Institute and Samara State Agricultural Academy, also allows us to conclude that the transition to a minimum (resource-saving) technology of grain cultivation is promising. It is established that the use of minimal tillage in crop rotation for a long time does not worsen most of the parameters of soil fertility compared to plowing, and such indicators as soil density, water properties, food regime and productivity are close in terms of both minimum processing and plowing.

Due to the biological characteristics of the crop and low water availability in the region, the potential yield of soy in the Volga steppe remains low (12-15C/ha). Increasing the efficiency of soy production is possible by reducing technological costs.

Since tillage accounts for a significant share (up to $30 \%$ ) in the structure of field crop cultivation costs, it is advisable to consider the possibility of minimizing tillage. Soybean crops in Russia cover an area of more than 3000 thousand hectares and are increasing every year. In General, over the past five years, its area has increased by $50 \%$. In the Samara region, soy is one of the most popular crops, its area of sowing is about 17 thousand hectares. [18].

Soybean crops in Russia have an area of more than 3 million hectares and this area is expanding every year. In general, over the past five years, its area has increased by $50 \%$. In Samara region, soy is one of the high-demand crops and its planted area is about 17 thousand hectares.

Issues on primary tillage, which are often connected with the possibility of reducing energy costs during the crop production by tillage minimizing, and usage of

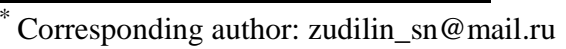


fertilizers, as well as their effect on optimizing the mineral nutrition of plants, are still under discussion [6].

An important role in optimizing the plant nutrition regime belongs to the soil tillage technologies, which determine the depth of incorporation and intensive mixing of fertilizers and plant residues in the topsoil, the parameters of water-air and thermal regimes and, consequently, the rate of biochemical processes [9-11].

One of the ways to increase the sustainability of agriculture in arid conditions is the soil conditioning. The main step in achieving this goal is to conserve and increase the content of humus and soil fertility in general through the systematic incorporation of organic matter in the form of manure and other organic fertilizers. Taking into account the high cost of manure, other cheaper sources of organics are required [12]. We assumed that the liquid and solid organic fertilizers produced by AgroPromSnab LLC could become such fertilizers.

\section{Materials and methods}

The aim of the research was to study the influence of primary soil tillage and organic fertilizer aftereffect on the yield of soybeans. Studies were carried out on the experimental field of the department of Land Management, Soil Science and Agricultural Chemistry in a grain-fallow rotation, where winter wheat was a forecrop of soy. Zoned soybean varieties that are well adapted to the conditions of Samara region were used in the experiment.

The experiment design included the following primary soil tillage variants: 1) plowing at $20-22 \mathrm{~cm}$ (control); 2) shallow tillage at $10-12 \mathrm{~cm} ; 3)$ zero tillage + non-selective herbicide application.

The experiment was repeated three times; the size of the plots was $780 \mathrm{~m}^{2}$.

In the first two experimental variants, immediately after harvesting the forecrop, preliminary shallow plowing with disks was carried out on a depth of $6-8 \mathrm{~cm}$. The remaining elements of soybean production technology were the same and generally accepted for the forest-steppe zone of Samara region in all variants of the experiment.

Since 2016, the study of the primary soil tillage for soybeans was carried out on fertilized and non-fertilized backgrounds. The fertilized background included the aftereffect of the following organic fertilizers applied on the fallow field: manure at a dose of $30 \mathrm{t} / \mathrm{ha}$, liquid organic fertilizer $(1 \mathrm{t})$ and solid organic fertilizer $(0.5 \mathrm{t})$. Liquid and solid (dry) forms of organic fertilizers were applied in an equivalent for nitrogen amount of manure.

Ensuring a deficit-free balance of organic matter in the soil is an indispensable rule of cultural farming, and the problem of increasing the productivity of agricultural crops while simultaneously preserving and reproducing soil fertility is currently the most acute and timely. Organic fertilizers play a special role in solving this problem.

Agropromsnab LLC produces new innovative organic fertilizers based on animal waste, crop residues in accordance with GOST 53117-08. Fertilizers are available in solid and liquid form, intended for use in agricultural production, horticulture, forestry, and on private plots. The basis of the new organic fertilizers is bird droppings, animal waste and seed husk with the addition of humic acids, fulvic acids and trace elements, using nanotechnology.

The main component for the production of fertilizers are organic substances obtained by processing raw materials with the UAP device (process activation unit), which allows decomposing organic substances into simpler ones. Then a consortium (community) of soiloriented microorganisms is selected (with the enrichment of directed bacteria and fungi). Due to this, the fertilizer is environmentally friendly for the biocenosis and soil, and the resulting products do not contain substances harmful to human health. During processing, all the necessary mineral components are stored. This destroys all pathogenic microflora, weed seeds, as well as cleavage and transfer of heavy metal salts to a non-toxic form. No chemical additives or GMOs are used in the production process.

The dry matter content in the solid form of fertilizer is $89.9 \%$, and in the liquid form is $2.2 \%$. Dry organic fertilizer is produced in polyethylene bags weighing 25 $\mathrm{kg}$, which is very convenient, since it allows you to avoid losses during transportation and storage. The mass fraction of total nitrogen in the fertilizer with the initial humidity of $5.28 \%$. In liquid fertilizer, the mass fraction of total nitrogen is $0.28 \%$ (at $97.8 \%$ humidity).Organic fertilizers were applied to the fallow field before the primary soil tillage.

The soil of the experimental field was a typical medium-thick heavy loam chernozem.

Observations and calculations were carried out according to generally accepted methods used in field and laboratory studies in agriculture [13, 14].

The reaping was carried out by a small-sized harvester TERRION. We used variance analysis for the mathematical processing of yield data [15].

Weather conditions during the years of study were different, which allowed us to assess the influence of factors objectively.

\section{Results and discussion}

Physical characteristics of soil are the basis for the formation of its fertility. They determine the whole complex of physical, water, air, temperature and biological processes that affects the mobilization of nutrients, their availability and utilization by plants. For leguminous crops, the optimal value of the addition density (volume mass) of the arable soil layer is 1.0-1.2 $\mathrm{g} / \mathrm{cm} 3$, a deviation from the optimal value leads to a decrease in productivity.

In the conducted studies, it was found that the amount of soil density in the spring period changed depending on the method of basic soil cultivation [16]. Measurement of a bulk density of the arable layer of typical chernozem showed that it was optimal only for plowing factor and contained $1.05 \mathrm{~g} / \mathrm{cm}^{3}$ (Table 1). 
Shallow tillage and no-till in the autumn period contributed to an increase in soil density by $0.06-0.09 \mathrm{~g} /$ $\mathrm{cm}^{3}$ in comparison with plowing. These differences were even more noticeable $\left(0.15 \mathrm{~g} / \mathrm{cm}^{3}\right)$ when observed in the $10-20 \mathrm{~cm}$ layer that negatively affected the development of nodule-forming bacteria. By the moment of harvesting, the soil was compacted on all variants, especially on plowing, and the data were aligned between the experimental options.

Table 1. Soil density and productive moisture reserves depending on the primary soil tillage (2007-2019)

\begin{tabular}{|c|c|c|c|c|}
\hline Indicators & Determination terms & $\begin{array}{c}\text { Plowing at 20-22 } \\
\mathrm{cm}(\text { control) }\end{array}$ & $\begin{array}{c}\text { Shallow tillage } \\
\text { at 10-12 cm }\end{array}$ & No-till \\
\hline $\begin{array}{c}\text { Bulk density of the layer 0-30 } \\
\mathrm{cm}, \mathrm{g} / \mathrm{cm}^{3}\end{array}$ & Before seeding & 1.05 & 1.11 & 1.14 \\
\cline { 2 - 5 } & Before harvesting & 1.16 & 1.16 & 1.18 \\
\hline $\begin{array}{c}\text { Productive moisture reserves } \\
\text { in the layer 0-100 cm }\end{array}$ & Before seeding & 162.4 & 161.1 & 158.5 \\
\cline { 2 - 5 } & Before harvesting & 39.3 & 40.6 & 39.3 \\
\hline
\end{tabular}

The main limiting factor for the yield of crops, including soybeans, in arid conditions is moisture. Under these conditions, the effectiveness of primary tillage technologies is largely determined by soil moisture reserves before seeding. Primary tillage did not affect significantly on the productive moisture reserves in the meter layer of soil. There were no critical differences in soil moisture reserves before harvesting as well. However, soybean plants that had been seeded after plowing used soil moisture 18.2-39.0\% more effectively on the formation of a unit of crop than after shallow tillage or no-till.

Weed control in soybean crops is a key reserve for increasing the yield of this crop [17]. The species composition of weeds was typical for the region. The total weediness of crops, both in the quantity and in the wet weight of weeds, did not vary widely in the experimental variants (Table 2), which was associated with the application of highly effective herbicides.

Table 2. Weediness of soybean crops before harvesting (2007-2019)

\begin{tabular}{|c|c|c|c|c|}
\hline Indicators & Unit of measurement & $\begin{array}{c}\text { Plowing at 20-22 } \\
\mathrm{cm}(\text { control })\end{array}$ & $\begin{array}{c}\text { Shallow tillage at } \\
10-12 \mathrm{~cm}\end{array}$ & No-till \\
\hline $\begin{array}{c}\text { Total amount of } \\
\text { weeds }\end{array}$ & $\mathrm{pcs} / \mathrm{m}^{2}$ & 35.5 & 38.8 & 39.4 \\
\cline { 2 - 5 } $\begin{array}{c}\text { Amount of } \\
\text { perennial weeds }\end{array}$ & $\mathrm{g} / \mathrm{m}^{2}$ & 125.3 & 138.4 & 147.6 \\
\cline { 2 - 5 } & $\mathrm{pcs} / \mathrm{m}^{2}$ & 2.4 & 2.4 & 3.3 \\
\hline
\end{tabular}

The predominant weeds were not perennial and mostly dicotyledonous, such as wild lettuce (Latuca sativa L.), green amaranth (Amaranthus retroflexus L.), and prostrate amaranth (Amaranthus blitoides $S$ / Wats). There was a small number of cereal weeds like yellow foxtail (Setaria pumila) and barnyard grass (Echinochloa crus-galli L.). Perennial weeds were represented by cursed thistle (Cirsium arvense), and field bindweed (Convolvulus arvensis). The primary tillage had a small effect on the species composition of weeds. Thus, shallow tillage and no-till was accompanied by an increase in the wet weight of weeds by 1.3 times in comparison with plowing.

One of the main efficiency criteria of the studied primary tillage technologies is crop yield. On average, over 13 years of research, the highest and most stable yields were provided by plowing. Shallow tillage and notill led to a significant $(0.25-0.44 \mathrm{t} / \mathrm{ha})$ crop shortage compared to the control (Table 3). That was because of both increased soil density and a higher crop weediness (in 1.5-2.0 times) with perennial weeds in the initial periods of growth, when the crop was growing slowly and suffered greatly from weeds. The application of herbicides does not usually solve this problem, especially with perennial weeds during this period of crop growth and development, which subsequently also negatively affects its productivity.

In our two-factor experiment, we did not only study the influence of primary tillage and aftereffect of organic fertilizers on soybean productivity, but we have been also studying their interaction for the period of three years. The results of the research are presented in Table 4.

They show that primary soil tillage and aftereffect of organic fertilizers had a significant impact on the bean yield of soy leguminous crop, but the interaction of abovementioned factors, as had been shown by statistical analysis of the results, was unreliable.

The greatest crop yield $1.45 \mathrm{t} /$ ha was collected by plowing, which was 0.25 and $0.44 \mathrm{t} /$ ha higher than by shallow tillage and no-till respectively.

The aftereffect of organic fertilizers (factor B) applied on the fallow field promoted the additional soybean yield of $0.17-0.18 \mathrm{t} /$ ha compared to the non-fertilized plot. New types of organic fertilizers were not worse than manure in terms of impact on productivity. 
Table 3. Soybean yield ( $\mathrm{t} / \mathrm{ha}$ ) depending on primary soil tillage

\begin{tabular}{|c|c|c|c|c|}
\hline Years & $\begin{array}{c}\text { Plowing at 20-22 cm } \\
(\text { control })\end{array}$ & $\begin{array}{c}\text { Shallow tillage at } \\
10-12 \mathrm{~cm}\end{array}$ & $\begin{array}{c}\text { The least significant } \\
\text { difference }(05) \\
\left(\text { LSD }_{05}\right) \mathrm{t} / \mathrm{ha}\end{array}$ \\
\hline 2007 & 1.41 & 1.35 & 1.28 & 0.24 \\
\hline 2008 & 2.50 & 1.91 & 1.77 & 0.49 \\
\hline 2009 & 1.41 & 1.25 & 0.93 & 0.28 \\
\hline 2010 & 0.98 & 0.91 & 0.80 & 0.19 \\
\hline 2011 & 1.99 & 1.42 & 0.95 & 0.10 \\
\hline 2012 & 1.68 & 1.52 & 1.41 & 0.18 \\
\hline 2013 & 1.75 & 1.20 & 0.62 & 0.09 \\
\hline 2014 & 0.96 & 0.81 & 0.68 & 0.25 \\
\hline 2015 & 0.92 & 0.85 & 0.96 & 0.18 \\
\hline 2016 & 1.26 & 1.20 & 0.71 & 0.09 \\
\hline 2017 & 0.97 & 0.71 & 1.30 & 0.12 \\
\hline 2018 & 1.53 & 1.39 & 0.72 & - \\
\hline 2019 & 1.45 & 1.06 & 1.01 & \\
\hline On an average & 1.45 & 1.20 & & \\
\hline
\end{tabular}

Table 4. Soybean yield ( $\mathrm{t} / \mathrm{ha}$ ) depending on the primary soil tillage and aftereffect of organic fertilizers $(2016,2018-2019)$

\begin{tabular}{|c|c|c|c|c|c|}
\hline \multicolumn{2}{|r|}{ Factors studied } & \multicolumn{3}{|c|}{ Years } & \multirow{2}{*}{$\begin{array}{c}\text { On an } \\
\text { average }\end{array}$} \\
\hline $\begin{array}{l}\text { Primary soil tillage } \\
\text { (factor A) }\end{array}$ & $\begin{array}{l}\text { Aftereffect of organic fertilizers } \\
\text { (factor B) }\end{array}$ & 2016 & 2018 & 2019 & \\
\hline \multirow{4}{*}{$\begin{array}{l}\text { Plowing at } 20-22 \mathrm{~cm} \\
\text { (control) }\end{array}$} & Fertilizer omitted & 1.06 & 1.40 & 1.28 & 1.25 \\
\hline & Manure & 1.42 & 1.62 & 1.39 & 1.48 \\
\hline & Dry organic fertilizer & 1.25 & 1.57 & 1.46 & 1.43 \\
\hline & Liquid organic fertilizer & 1.32 & 1.55 & 1.53 & 1.47 \\
\hline \multirow{4}{*}{$\begin{array}{l}\text { Shallow tillage at } 10- \\
12 \mathrm{~cm}\end{array}$} & Fertilizer omitted & 1.03 & 1.27 & 0.90 & 1.07 \\
\hline & Manure & 1.36 & 1.44 & 1.05 & 1.25 \\
\hline & Dry organic fertilizer & 1.21 & 1.44 & 1.10 & 1.25 \\
\hline & Liquid organic fertilizer & 1.22 & 1.39 & 1.09 & 1.23 \\
\hline \multirow[t]{4}{*}{ No-till } & Fertilizer omitted & 0.90 & 1.15 & 0.60 & 0.88 \\
\hline & Manure & 1.09 & 1.28 & 0.67 & 1.01 \\
\hline & Dry organic fertilizer & 0.92 & 1.39 & 0.77 & 1.03 \\
\hline & Liquid organic fertilizer & 0.94 & 1.38 & 0.76 & 1.03 \\
\hline \multicolumn{6}{|c|}{$\begin{array}{l}\text { 2016: } \mathrm{LSD}_{05} \text { total }=0.30 ; \mathrm{LSD}_{05} \mathrm{~A}=0.15 ; \mathrm{LSD}_{05 \mathrm{~B}} \text { and } \mathrm{AB}=0.18 . \\
\text { 2018: } \mathrm{LSD}_{05} \text { total }=0.13 ; \mathrm{LSD}_{05}=0.06 ; \mathrm{LSD}_{05} \mathrm{~B} \text { and } \mathrm{AB}=0.07 . \\
\text { 2019: } \mathrm{LSD}_{05} \text { total }=0.13 ; \mathrm{LSD}_{05 \mathrm{~A}}=0.07 ; \mathrm{LSD}_{05 \mathrm{~B} \text { and } \mathrm{AB}}=0.08\end{array}$} \\
\hline
\end{tabular}

\section{Conclusion}

Thus, on the chernozems of Trans-Volga forest-steppe, plowing at $20-22 \mathrm{~cm}$ in comparison with shallow tillage or no-till provides soybeans with more favorable conditions for growth and development, and thereby increases the crop yield by $0.25-0.44 \mathrm{t} / \mathrm{ha}$. The aftereffect of organic fertilizers promotes an extra yield of 0.17-0.18 $\mathrm{t} /$ ha compared with the non-fertilized variant.

\section{References}

1. A.Yu. Kruglikov, Methods of tillage and fertilizer application for soybeans cultivated in the graincultivated crop rotation of the Central Black Earth Region, abstract of cand. diss. (Kursk, 2012) 20 p.

2. V.A. Vorontsov, Special aspects of soybean cultivation technology, Sugar beet, 2, 42-44 (2015)
3. A.Yu. Khadikov, The effect of fertilizers on productivity and soybean grain quality and soil fertility of leached chernozem of North OssetiaAlania, abstract of cand. diss. (Vladikavkaz, 2012) 20 p.

4. L.E. Cruz-Suarez, Apparent dry matter, energy protein and amino acid digestibility of four soybean ingredients in white vannamei, Aquaculture (2009)

5. K. Liu, Soybeans: chemistry, technology and utilization (Aspen publishers, Gaithersburg, Maryland, 1997 $532 \mathrm{p}$.

6. S.G. Smirnov, M.M. Nafikov, V.N. Fomin, Productivity and quality of soybean grain depending on the technology of primary tillage and fertilizers, Feed production, 6, 15-18 (2013)

7. A.I. Katyuk, V.V. Zubkov, Ecological plasticity and stability of promising soybean lines in the Middle Volga region, Young scientist, 22.2 (102.2), 45-47 (2015) Available https://moluch.ru/archive/102/23430/ 
8. V.G. Kutilkin, The influence of the primary tillage on soybean yield, in: Achievements of science to the agro-industrial complex: Proc., 79-82 (2014)

9. N.S. Matyuk, V.D. Polin, E.D. Abrashkina, Productivity of crops and soil fertility depending on its processing and fertilizers, Soil Fertility, 1(170), 38-40 (2008)

10. M.A. Mazirov, N.S. Matyuk, V.D. Polin, N.V. Malakhov, The influence of different tillage systems and fertilizers on the fertility of sod-podzolic soil, Agriculture, 2, 33-36 (2018)

11. J.B. Notron, J. Eusebleus, M. Notron, et al., Loss and Recovery of Soil Organic Carbon and Nitrogen in a Semiarid Agroecosystem, Soil Organic Society of America J., 76(2), 505-514 (2012)

12. I.D. Sosnina, The influence of types of organic and mineral fertilizers on grain productivity, arable land productivity and soil fertility conservation,
Achievements of science and technology of the agroindustrial complex, 5, 32-35 (2013)

13. I.P. Vasiliev, A.M. Tulikov, G.I. Bazdyrev, et al. Workshop in Agriculture: A training manual (KolosS, Moscow, 2004) 424 p.

14. Methodology of state variety testing of crops. The General Part, (Kolos, Moscow, 1971) 248 p.

15. S.N. Zudilin, S.N. Shevchenko, V.G. Kutilkin, Methodology of experimental work: a training manual (RIO of the Samara State Agricultural Academy, Kinel, 2016) 147 p.

16. V.I. Turusov, V.M. Garmashov, The effectiveness of various techniques and tillage systems in the rotation of peas - winter wheat in the southeast of the Central Black Sea region, Agriculture, 4, 9-14 (2018)

17. A.S. Golubev, P.I. Borushko, K.V. Zheltova, New herbicide Geyser to protect soybeans, Agriculture, 6 , 37-40 (2018) 